\title{
液中分散粒子の沈降界面形成過程の解析
}

\section{Analysis of Settling Interface Formation Process in Suspension}

\author{
杉本 理充, 廣瀬 仁嗣, 森 英利, 椿 淳一郎 \\ Tadamitsu Sugimoto, Hitoshi Hirose, Hidetoshi Mori, JunIchiro Tsubaki
}

\begin{abstract}
The present paper deals with the formation process of settling interface. Settling experiments and settling simulations showed that the settling interface is caused by the horizontal percolation of settling particles. In the case of low solid content, dispersed particles and/or agglomerates repeat collisions in the initial stage of settling, and form a settling interface. In the case of high solid content, particles form a network structure immediately after the settling starts, causing the zone settling.
\end{abstract}

Key Words : Settling interface, Particle percolation, Slurry, Particle sedimentation

\section{1. 緒言}

固液系スラリーの濃縮過程は, ファインセラミック ス成形プロセスや污水浄化システムなど様々な工業プ ロセスに含まれている。製品のさらなる高機能化およ び分離の高度化が要求される現在, 対象となる粒子の 大きさはますます小さくなり，粒子挙動は複雑なもの になってきている。粒子の沈降挙動は, 沈降中の粒子 の集合状態と密接な関係がある。沈降中の粒子の集合 状態は，粒子特性やスラリ一調製条件に支配される。 粒子の沈降挙動は, 堆積層の構造に影響を及ぼすが, 沈降中の粒子の集合状態が十分に把握されていないこ とも原因となって, 固液系スラリーの調製は, 技術者 の試行錯誤で行われていることが多い。

そこで本研究では, 液中に分散した粒子が連続体化 するまでに関し, 粒子径分布, 初期粒子濃度および付 着性が沈降挙動に及ぼす影響を把握することを試みて いる。従来のシミュレーションは，粒子あるいはあら かじめブラウン運動により生成した凝集体を, 個々に 沈降場上部のランダムな位置より順次沈降させて充填 層を構成する方法を用い，充填層構造に及ぼす粒子径 分布および粒子同士の付着性の影響について考察され た ${ }^{1 \sim 5)}$ 。しかしながら，この方法では沈降途中におけ

\footnotetext{
2000年8月 31 日受付

第 36 回夏期シンポジウム（2000年 7 月, 葉山）にて発表 名古屋大学工学研究科物質制御工学専攻

（テ464-8603 名古屋市千種区不老町）TEL 052-789-2574 Department of Molecular Design and Engineering, University of Nagoya

(Furo-cho, Chikusa-ku, Nagoya 464-8603)
}

る粒子の沈降挙動や集合状態を把握することは困難で ある。そこで，本研究では，沈降場中に粒子を必要な 数発生させ，一斉に沈降させるシミュレーションを使 用した。現在まで，単分散で高分子添加剂による架

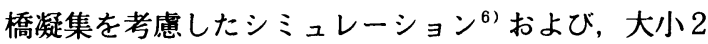
粒子を用いた沈降シミュレーション常を行った。これ らの結果より, 沈降速度差により生ずる沈降途中で の粒子同士の衝㔖・凝集が, 沈降挙動に影響を及ほ し, 連続体の構造や充填率に影響を及ぼすことが示さ れた。

いままでの固液分離の研究では，いかに効率良く液 体を得るかに重点をおいていたため，沈降する粒子の 挙動は，マクロな沈降様式で分類されているに過ぎな $\left({ }^{8)}\right.$ 。沈降様式の分類は, 初期粒子濃度と付着性の関 係より定性的に行われている。また，観測された沈降 様式および観測された沈降界面の沈降速度より, 沈降 中の粒子の状態の予測を試みているが9)，沈降様式の 違いが発生する機構や沈降界面の形成機構に関しては 検討されていない。

そこで本報では，沈降界面の形成過程に着目し，粒 子の粒径比や組成比，および初期粒子濃度が及ぼす影 響を把握することを目的とし，沈降実験および沈降シ ミュレーションにより検討を行った。

\section{2. 実験およびシミュレーション方法}

\section{1 沈降実験}

固液分離の研究では, 沈降様式の違いを初期粒子 濃度と粒子同士の付着性との関係で整理しているた $め^{8)}$, あらためて, 確認のための沈降実験を行った。 
Table 1 Simulation condition of binary dispersion

\begin{tabular}{ccccccc}
\hline & \multicolumn{5}{c}{ Solids content (area \%) } \\
$d_{\mathrm{pL}} / d_{\mathrm{pS}}$ & $f_{\mathrm{L}}: f_{\mathrm{S}}$ & 0.1 & 0.5 & 1.0 & 5.0 & 10.0 \\
\hline 1.4 & $2: 8$ & $\bigcirc$ & $\bigcirc$ & $\bigcirc$ & - & - \\
1.4 & $8: 2$ & $\bigcirc$ & $\bigcirc$ & $\bigcirc$ & - & - \\
2.0 & $2: 8$ & $\bigcirc$ & $\bigcirc$ & $\bigcirc$ & - & - \\
2.0 & $8: 2$ & $\bigcirc$ & $\bigcirc$ & $\bigcirc$ & $\bigcirc$ & $\bigcirc$ \\
\hline
\end{tabular}

粒子同士の付着性を変化させるため, 凝集剂を使用 して調製した粒子径 $5.5 \mu \mathrm{m}$ および $3.0 \mu \mathrm{m}$ のアルミ ナ研磨剤（WA2500, WA4000 フジミインコーポレー テッド(桻製）を体積割合 $4: 6$ で混合し, 超音波浴槽 で 5 分間分散操作を行い，スラリーを作製した。初期 粒子濃度は $5,7,10,14,20,40 \mathrm{vol} \%$ とし，凝集剂に はカリウムミョウバン（キシダ化学(制製）を使用 し, 添加量は $0,5,10,25,50 \mathrm{mg} / 100 \mathrm{~g}$-alumina と した。

沈降実験では, 内径 $20 \mathrm{~mm}$, 高さ $160 \mathrm{~mm}$ のアク リル製円筒を使用し， スラリーの仕込み高さを 150 $\mathrm{mm}$ とし, 媒液とスラリーとの沈降界面形成の有無 を観察した。沈降界面の形成が観測された場合, 沈降 界面の深さの経時変化を観測した。

\section{2 シミュレーション}

本シミュレーションは, 沈降途中の粒子同士が衝 突・凝集を繰り返すことにより, 凝集体が成長し, 沈 降界面を形成する過程を模擬するため, 衝乫を起こす ためのパラメータとして粒子径分布, 粒子同士の衝突 頻度を表すパラメータとして初期粒子濃度, そして, 凝集体の作りやすさを表すパラメータとして付着性を 用いた。本報では，粒子径分布に関しては，もっとも 単純な場合である大小 2 粒子の粒径比および組成比を 変化させ, 付着性に関しては, 粒子同士が衝突した場 合必ず凝集し，凝集体は衝突時の形状を保ちながら沈 降するとして取り扱った。また，シミュレーションで は, 簡単化のために, 沈降中の粒子は回転やブラウン 運動をしないと仮定した。

シミュレーションは，2 次元で行った。小粒子の粒 子径 $d_{\mathrm{pS}}$ を基準にし，大粒子を $d_{\mathrm{pL}} / d_{\mathrm{pS}}=1.4$ および 2.0 , 沈降場の鉛直方向長さを $10,000 d_{\mathrm{pS}}$, 水平方向 長さを $500 d_{\mathrm{pS}}$ とした。沈降場中に大小 2 粒子の粒径 比や組成比および初期粒子濃度を変化させ，アルミナ 粒子を水媒体中で重力沈降させた場合を想定して行っ た。全ての粒子は同一平面上にあり，濃度および組成 比は, 沈降平面と粒子の断面積の比で取り扱った。沈 降場側面には，周期境界条件を適用した。Table 1 の

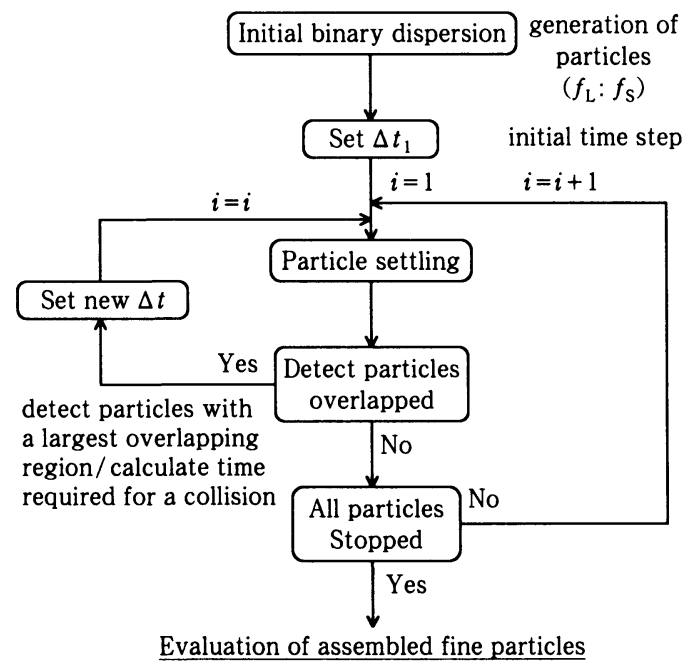

Fig. 1 Schematic diagram for simulating settling interface formation proccess

○印で示した条件でシミュレーションを行った。

粒子の沈降は, Stokesの沈降速度式に従うとし, 粒子同士が完全に接触して凝集体を形成した場合は, 凝集体を構成する全粒子の球体積相当径に換算し，沈 降速度を求めた。小粒子 1 個の沈降速度 $v_{1 \mathrm{~s}}$ を基準と し，粒子径 $d_{\mathrm{pL}}$ および $d_{\mathrm{pS}}$ の大小粒子が，それぞれ $m$ および $n$ 個で構成される凝集体の沈降速度を便宜的 に

$$
v_{\mathrm{m} n}=\frac{\left(m \cdot d_{\mathrm{pL}}^{3}+n \cdot d_{\mathrm{pS}}^{3}\right)^{\frac{2}{3}}}{d_{\mathrm{pS}}^{2}} v_{1 \mathrm{~S}}
$$

と表わした。

シミュレーションでは，Fig. 1に示すように，ま ず，乱数により粒子座標を設定し，各粒子が接触せ ず，重ならないように所定の初期粒子濃度 $\phi_{0}$ （area \%)になるまで，沈降場中に発生させる。次に沈降速 度の最も速い粒子あるいは凝集体を検索し，設定した 最大沈降距離（=0.5 $\left.d_{\mathrm{pS}}\right)$ をその速度で割り，時間を 求め沈降させる。その際，粒子同士が重なったものが 
ある場合は，それら粒子が衝突する時間を求め，この 時間で沈降し直し, 接触・凝集判定を行い, 全粒子が 沈降を終えるまで繰り返した ${ }^{7)} 。$

\section{3. 結果および考察}

\section{1 沈降実験}

Fig. 2 は，沈降界面形成の有無を示す。この図では, ‘○’はスラリ一層と清澄層との明確な沈降界面が観測 された場合である界面沈降, ‘次はラリー層中に濃 淡による沈降界面が観測された場合である成相沈降,

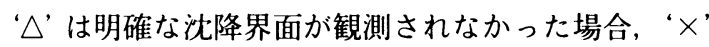
は流動化しなかったためスラリーとして調製できなか った場合を示す。また， ‘’は，沈降開始時では成相 沈降のように挙動するが, 数 $\mathrm{cm}$ 沈降した後に沈降界 面が明確になり, 更に沈降した後上部の賏濁層が沈降 界面に追い付き，界面沈降と同様な沈降挙動を示した 場合である。この図から，一般的な沈降様式の違いが 確かめられた。

そこで, 沈降界面か観測された条件のうち, 付着性 が強いと思われ, 粒子濃度により全ての沈降挙動が観 測された，凝集剤添加量 $50 \mathrm{mg} / 100 \mathrm{~g}$ - alumina の場 合に着目し，粒子濃度 $10 \mathrm{vol} . \%$ 付近での沈降様式の 違いについて検討を行った。

\section{2 シミュレーション}

沈降挙動を検討するために, 微粒子の集合状態とし $\tau$ ，粒子濃度比 $\phi / \phi_{0}$, 配位数 $k$ および分散指数 $a$ の 適用を試みた ${ }^{10)}$ 。粒子濃度比 $\phi / \phi_{0}$ は, 初期仕込み濃 度に対する比, 配位数 $k$ は接触点数の 2 倍を 1 次粒 子数で割った值, 分散指数 $a$ は次式のように与え た。

$$
a=\frac{n-1}{N}
$$

ここで, $N$ は 1 次粒子数, $n$ は凝集体を一つの粒子と みなした場合の粒子個数で, 全ての粒子が一つの凝集 体となり，連続体を形成した時点で $a=0$ となる。

また, 同一条件で比較を行うため, Fig. 3に示す単 位深さを定義した。ここでは, 水平方向への粒子の パーコレーションが沈降界面を形成すると考え, 以下 のように単位深さを考えた。まず，Fig. 3 (a) に示し たように 2 次元の場合は, 粒子がパーコレーションす るためには, 幾何学的に粒子の投影長さの総和が沈降 場の幅と一致する必要がある。その条件が満たされる 深さを $H_{\mathrm{u}}^{\prime}$ とし, 次のように導いた。まず, 沈降場の 任意の位置に存在し, 沈降場の幅に等しい長さをもつ

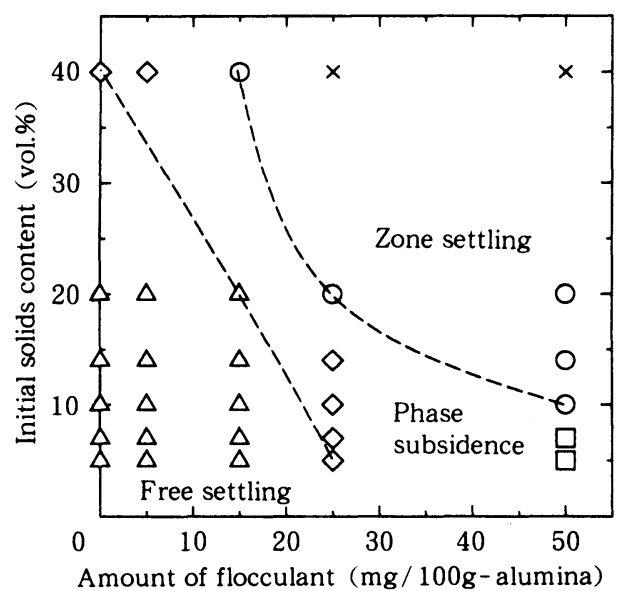

Fig. 2 Dependency of amount of flocculant and initial solids content on the settling process : $\bigcirc$ is zone settling, $\square$ is phase subsidence to zone settling, $\diamond$ is phase subsidence, $\triangle$ is free settling and $X$ is not able to prepare as slurry

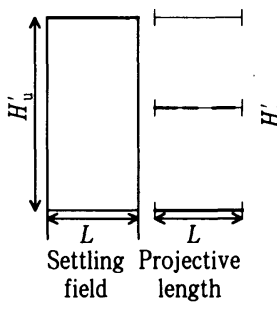

(a) $H_{u}^{\prime}$

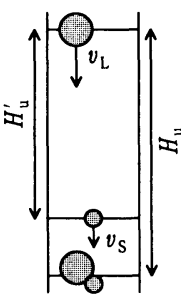

(b) $H_{\mathrm{u}}, T_{\mathrm{u}}$

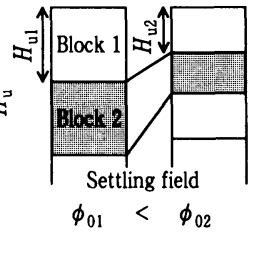

(c) Comparison
Fig. 3 Estimation model of unit height, $H_{\mathrm{u}}$, and unit time, $T_{\mathrm{u}}$

水平線分 $\mathrm{L}$ 上に粒子径 $d_{\mathrm{p}}$ の $n$ 個の粒子を投影した場 合を考える。線分 $L$ 上にある微小長さ $\mathrm{d} l$ の範囲に存 在する粒子が形成する投影長さ $\mathrm{d} L_{\mathrm{d}}$ は,

$$
\mathrm{d} L_{\mathrm{d}}=n \cdot d_{\mathrm{p}} \frac{\mathrm{d} l}{L}
$$

となる。ここで, $i$ 成分の粒子の粒子径を $d_{\mathrm{pi}}$, 濃度 を $\phi_{\mathrm{i}}$ としたときの粒子個数 $n_{\mathrm{i}}$ は,

$$
\phi_{\mathrm{i}}=\frac{n_{\mathrm{i}} \frac{\pi}{4} d_{\mathrm{pi}}^{2}}{L \cdot H}
$$

より

$$
n_{\mathrm{i}}=\frac{4 \phi_{\mathrm{i}} L \cdot H}{\pi d_{\mathrm{pi}}^{2}}
$$



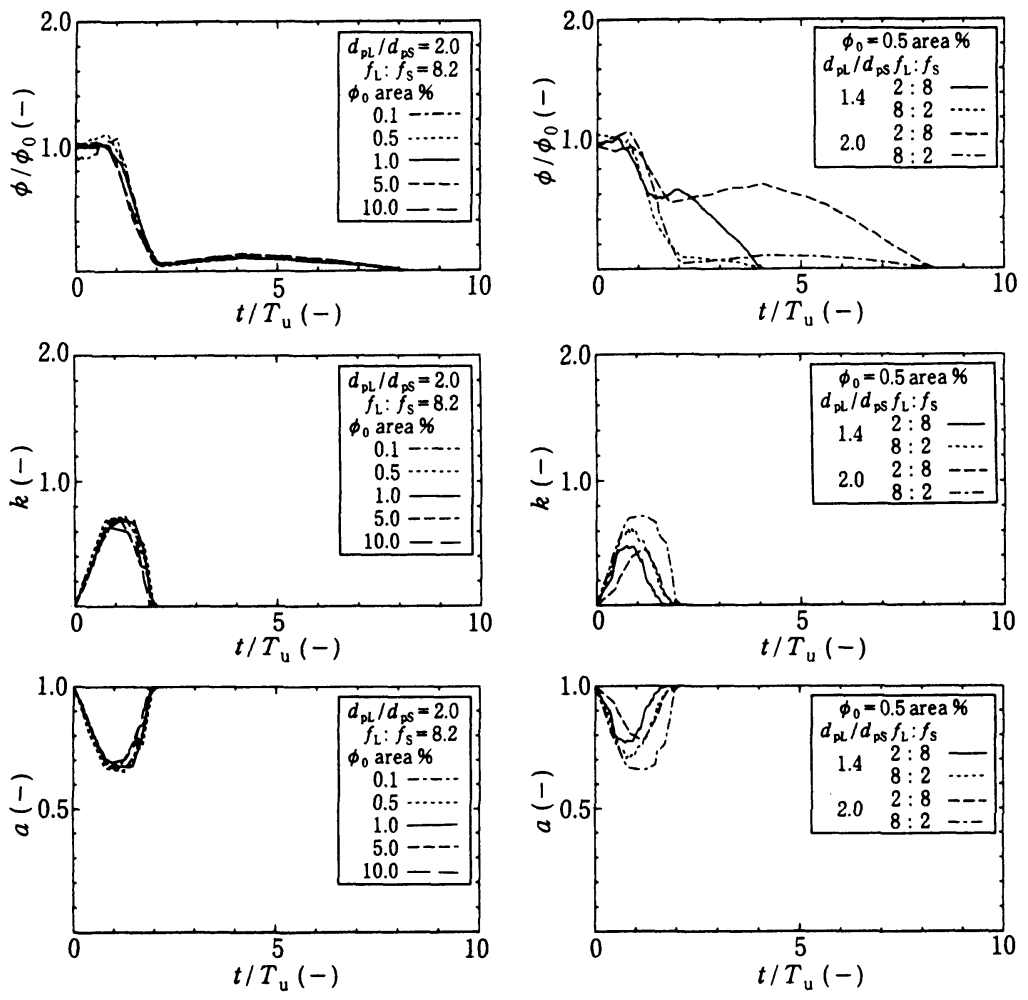

(a) Effect of solids content $\left(d_{\mathrm{pL}} / d_{\mathrm{ps}}=2.0, f_{\mathrm{L}}: f_{\mathrm{S}}=8: 2\right)$

(b) Effect of particle diameter fraction and solid fraction $\left(\phi_{0}=0.5\right.$ area $\left.\%\right)$

Fig. 4 Time change in characteristic values of $a, k$ and $\phi / \phi_{0}$ in the range $1.0 \leq H / H_{\mathrm{u}} \leq 2.0$

となる。Eqs. (3)，（4）より期待長さ $L_{\mathrm{d}}$ は,

$$
\begin{aligned}
\int_{0}^{L_{d}} \mathrm{~d} L_{\mathrm{d}} & =\int_{0}^{L} \sum_{i} \frac{4 \phi_{\mathrm{i}} L \cdot H}{\pi d_{\mathrm{pi}}^{2}} d_{\mathrm{pi}} \frac{\mathrm{d} l}{L} \\
L_{\mathrm{d}} & =\frac{4 H}{\pi} \sum_{i} \frac{\phi_{\mathrm{i}}}{d_{\mathrm{pi}}} \int_{0}^{L} \mathrm{~d} l \\
& =\frac{4 H}{\pi} \sum_{i} \frac{\phi_{\mathrm{i}}}{d_{\mathrm{pi}}} L
\end{aligned}
$$

と導かれ，粒子の投影長さ $L_{\mathrm{d}}=L$ のとき, $H=H_{\mathrm{u}}^{\prime}$ と 定義したことにより

$$
H_{\mathrm{u}}^{\prime}=\frac{\pi}{4} \frac{1}{\sum \frac{\phi_{\mathrm{i}}}{d_{\mathrm{pi}}}}
$$

となる。大小 2 粒子の場合, Fig. 3-（b）で示すよう に，深さ $H_{\mathrm{u}}^{\prime}$ の上部にある速度 $v_{\mathrm{L}}$ の大粒子が，深さ $H_{\mathrm{u}}^{\prime}$ の下部にある速度 $v_{\mathrm{S}}$ の小粒子に衝突するまでに は, 深さ $H_{\mathrm{u}}$ および時間 $T_{\mathrm{u}}$ を必要とするので, 次式
で与えられる $H_{\mathrm{u}}, T_{\mathrm{u}}$ をそれぞれ単位深さ, 単位時間 と定義した。

$$
H_{\mathrm{u}}=v_{\mathrm{L}} T_{\mathrm{u}}=H_{\mathrm{u}}^{\prime}+v_{\mathrm{S}} T_{\mathrm{u}}
$$

比較区間は, Fig. 3- (c) で示すように沈降場上部よ り $H_{\mathrm{u}}$ で分割し，比較は沈降場上部より数えて同じ区 間同士で行った。

Fig. 4 は，微粒子の集合状態を表す 3 パラメータの 経時変化の 1 例を示す。この図は，上から 2 番目の区 間の結果であり, (a) は粒径比 $d_{\mathrm{pL}} / d_{\mathrm{pS}}=2.0$, 組成比 $f_{\mathrm{L}}: f_{\mathrm{S}}=8: 2$ における粒子濃度が変化した場合，(b) は初期濃度 $\phi_{0}=0.5$ area \% における粒径比および組 成比が変化した場合である。

Fig. 4-(a) および（b）ともに，t/T $T_{\mathrm{u}} \leq 1.0$ では， $a$ が減少し， $k$ が増加することより，粒子同士が衝突 し凝集することを示す。また， $\phi / \phi_{0}$ が増加または変 化しないことから，上部の区間から粒子や凝集体が供 給されていることを示す。 $1.0<t / T_{\mathrm{u}} \leq 2.0$ では， $a$ が 


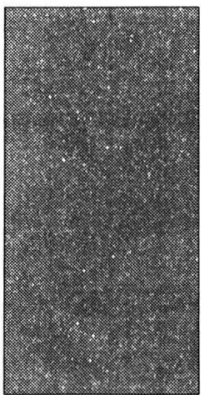

(a) $t=0(\mathrm{~s})$

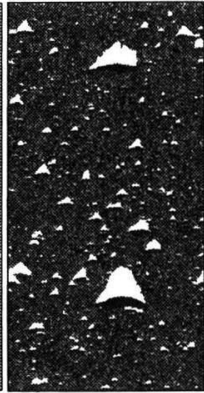

(b) $4.4(\mathrm{~s})$

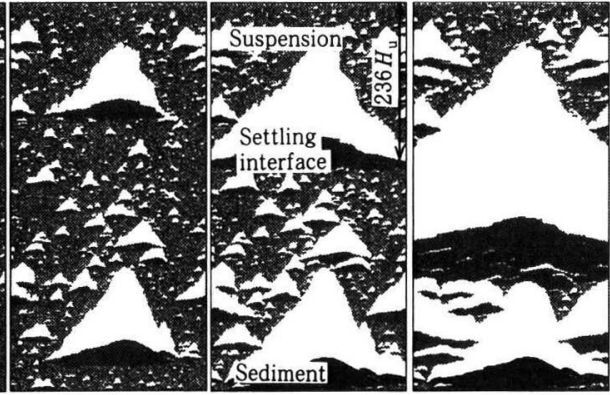

(d) $5.2(\mathrm{~s})$

(e) $5.5(\mathrm{~s})$

Fig. 5 Simulation result for the formation process of the settling interface

増加し， $k$ が減少したことから, 凝集体が減少したこ とを示す。また， $\phi / \phi_{0}$ が咸少したことより，粒子や 凝集体が下部の区間へ排出されていることを示す。 $t / T_{\mathrm{u}}>2.0$ における $a=1.0$ かつ $\phi / \phi_{0} \neq 0$ の範囲は, 衝突に関与しなかった小粒子の自由沈降を示す。この 沈降挙動が大きく変化する $t / T_{\mathrm{u}}$ の值は, 比較区間に 依存する。この場合, 比較区間が上から 2 番目である ため, $t / T_{\mathrm{u}}=2.0$ を境に粒子挙動が大きく変化した。

Fig. 4-(a) より，すべての曲線がほぼ一致してい ることから, 濃度の影響がなく, 同一沈降挙動である ことがわかった。これは，単位深さ $H_{\mathrm{u}}$ で分割した区 間を考えることより，濃度が変化しても， $H_{\mathrm{u}}$ および $T_{\mathrm{u}}$ 単位で粒子状態や沈降挙動に相似性があることを 示している。

Fig. 4-(b) では, 組成比および粒径比の影響が 見られた。組成比に関しては, 大小粒子の個数比す なわち, $f_{\mathrm{L}}: f_{\mathrm{S}}=2: 8$ では, $d_{\mathrm{pL}} / d_{\mathrm{pS}}=2.0$ の場合の個 数比 $f_{\mathrm{NL}} / f_{\mathrm{NS}}=0.06, d_{\mathrm{pL}} / d_{\mathrm{pS}}=1.4$ の場合の個数比 $f_{\mathrm{NL}} / f_{\mathrm{NS}}=0.13$ と大粒子が小粒子に比べ粒子個数が非 常に少なく, $f_{\mathrm{L}}: f_{\mathrm{S}}=8: 2$ では, $d_{\mathrm{pL}} / d_{\mathrm{pS}}=2.0$ の場合 の個数比 $f_{\mathrm{NL}} / f_{\mathrm{NS}}=1.0, d_{\mathrm{pL}} / d_{\mathrm{pS}}=1.4$ の場合の個数 比 $f_{\mathrm{NL}} / f_{\mathrm{NS}}=2.0$ 之, 大粒子と小粒子の粒子個数が等 しいか大粒子の粒子個数が多いことが影響していると 考えられる。まず, $\phi / \phi_{0}$ に関しては, $f_{\mathrm{L}}: f_{\mathrm{S}}=2: 8$ で は大粒子によってトラップされる小粒子が少ないため に，上部の区間にも未凝集の小粒子が多く残ってお り，大粒子や凝集体は小粒子よりも短い時間で下部の 区間へ排出され，いったん值は減少するが，未凝集の 小粒子が上部の区間から供給されるため, $t / T_{\mathrm{u}}=1.5$ 付近から，值が一定あるいは増加する傾向を示した。 これに対し， $f_{\mathrm{L}}: f_{\mathrm{S}}=8: 2$ では, 大粒子によってほほ 総ての小粒子がトラップされるため, 上部の区間にも 未凝集の小粒子がほとんど残っておらず，大粒子や凝
集体の下部の区間への排出量が小粒子の上の区間から の供給量より上回っていることから，值が減少する傾 向を示した。また，同一粒径比で組成比が $a$ および $k$ に及ぼす影響を見てみると, $f_{\mathrm{L}}: f_{\mathrm{S}}=8: 2$ では, 大 粒子の個数が小粒子の個数之等しいあるいは多いこと から，未凝集の 1 次粒子が減るため, $a$ の值は小さ く,kの值は大きくなった。さらに, 同一組成比で粒 径比が $a$ および $k$ に及ぼす影響を見てみると, 粒径 比が大きいほど衝突頻度が大きくなるため， $a$ の值は 小さく, $k$ の值は大きくなった。

他の区間においても, 同一粒径比および組成比の場 合では，粒子濃度によらず同一の粒子集合状態を得ら れたため，粒子が完全に分散し，衝突した粒子同士は 必ず凝集する場合には，粒子濃度によらず $H_{\mathrm{u}}$ および $T_{\mathrm{u}}$ により沈降挙動を整理可能であることが示され た。

また，シミュレーションでは 10area \% の場合のみ 沈降途中で, 粒子の水平方向へのパーコレーションが 観測された。形成過程を Fig. 5に示す。時間は, $1 \mu \mathrm{m}$ のアルミナ粒子が水中を沈降すると想定した場合の值 である。重力方向の座標のみ $1 / 10$ に縮小した。粒子 の色が薄いものは 1 次粒子, 中間のものは凝集体, 濃 いものは堆積層を示す。図より沈降中の粒子が衝突・ 凝集を繰り返し, 凝集体が成長し, パーコレーション する過程が模擬された。

この結果より, パーコレーションした位置は, 236 $H_{\mathrm{u}}$ であった。この結果と実験結果との比較を試み た。

\section{3 沈降界面形成過程}

沈降実験結果を 2 次元のシミュレーション結果と比 較するため, 3 次元の場合の単位深さ $H_{\mathrm{u}}$ および単位 時間 $T_{\mathrm{u}}$ を求めた。ここでは, 3 次元の沈降界面は, 沈降場断面の全てを覆うような粒子の水平方向への 


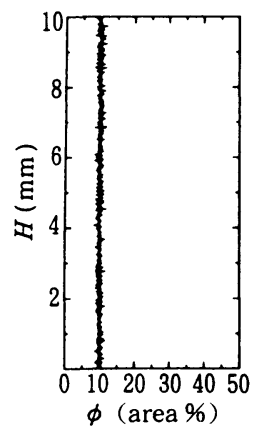

(a) $t=0$ (s)

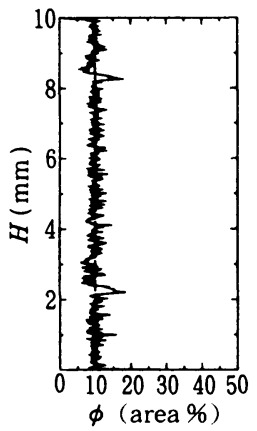

(b) $4.4(\mathrm{~s})$

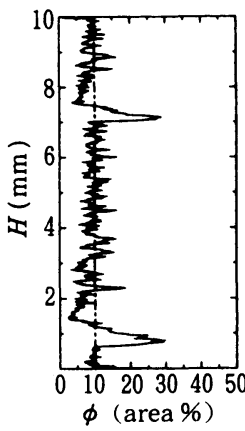

(c) $5.0(\mathrm{~s})$

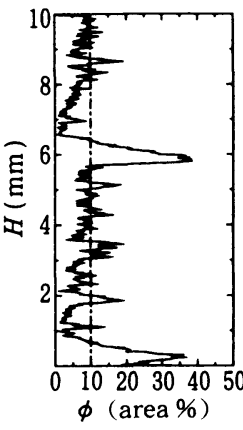

(d) $5.2(\mathrm{~s})$

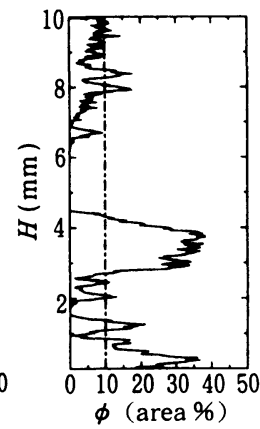

(e) $5.5(\mathrm{~s})$

Fig. 6 Simulated solids content distribution

Table 2 Relation of solids content to unit height, $H_{\mathrm{u}}$

\begin{tabular}{ccc}
\hline$\phi_{0}($ vol. \%) & $H_{\mathrm{u}}(\mu \mathrm{m})$ & $236 H_{\mathrm{u}}(\mathrm{mm})$ \\
\hline 5.0 & 70 & 16.5 \\
7.0 & 50 & 11.8 \\
10.0 & 35 & 8.3 \\
14.0 & 25 & 5.9 \\
20.0 & 17 & 4.0 \\
\hline
\end{tabular}

パーコレーションにより形成すると考えた。3 次元の 場合, 沈降場断面の全てを覆うように粒子がパーコ レーションをするためには, 幾何学的に粒子の投影面 積の総和が沈降場の断面積と一致する必要がある。そ の条件を満たす媣さを $H_{\mathrm{u}}^{\prime}$ とし, 2 次元と同様の方法 より,

$$
H_{\mathrm{u}}^{\prime}=\frac{2}{3} \frac{1}{\sum \frac{\phi_{\mathrm{i}}}{d_{\mathrm{pi}}}}
$$

と導かれた。ここでは, 粒子の沈降速度には, Steinour 式による沈降速度を用い, 各粒子の沈降速 度, 粒子径および濃度をEqs. (8)，（7）に代入し，実 験結果の $H_{\mathrm{u}}$ および $T_{\mathrm{u}}$ を求めた。 Table 2 に $H_{\mathrm{u}}$ の值 を示す。また, 2 次元のシミュレーション結果から得 られた粒子のパーコレーションが観測された位置であ る $236 H_{\mathrm{u}}$ の值も示す。パーコレーションが観測され る $236 H_{\mathrm{u}}$ の值と Fig. 2 の沈降挙動とを比較すると, 粒子濃度 $5,7 \mathrm{vol} . \%$ では, 数 $\mathrm{cm}$ 沈降した後に明確な 沈降界面を形成したことから実験結果と本シミュレー ション結果とが定性的に合っていると考えられる。こ のことから粒子濃度が違う場合においても，投影面へ の粒子の投影状態が同じ場合では, 粒子の沈降挙動が 等しくなることが示唆される。したがって, 粒子濃度
が低い場合，高い場合と比へ粒子の投影状態が等しく なるまでの距離は, 長くなることから, 粒子濃度が低 く, 明確な沈降界面が観測されない場合は, 沈降場の 長さが沈降界面形成を示す投影状態の長さに達してい ない。このことから, 粒子濃度が低い場合でも, 沈降 場の長さを十分長くすることにより, 沈降界面を形成 することが示唆される。これに対し， $10 \mathrm{vol} \%$ 以上 では, $1 \mathrm{~mm}$ も沈降しないうちに沈降界面の形成を観 測したため, 本シミュレーションとは異なる界面形成 機構であることが考えられる。

粒子濃度 5, 7vol.\% の場合では, 沈降初期には明確 な沈降界面は観測されず，時間とともに沈降界面が明 確になってきたことから，シミュレーションにおいて も同様な傾向を示すか否かを確認するため, Fig. 5の 濃度分布を求め，Fig. 6に示す。図より，沈降界面の 濃度が一番高く, 沈降界面の直上部分では濃度が低 く, 沈降場上部に近づくにつれ濃度が増加し, また, 沈降界面より下の領域において, 堆積層付近まで徐々 に濃度が低下している。沈降界面が時間とともに明確 になることを本シミュレーションで模擬できたと考え られる。しかしながら, 数\%以上のスラリー濃度で光 の透過率が 0 に近づき, 数\%以上の濃度の違いを観測 することは困難であるため, 実験結果との対応は難し い。また, 実際の沈降では, スラリ一の密度分布や置 換流の影響によりスラリーが対流し，スラリーの濃度 が一様になるように作用すると考えられる。本シミュ レーションをこのような液体の流れの影響を考慮した ものに改善したならば，実験で観測されたような濃度 分布により近づくと期待される。

粒子濃度 $10 \mathrm{vol} . \%$ 以上の場合では，高濃度になる につれ粒子間距離が小さくなり，粒子同士の相互作用 による引力が働きやすくなる。そのため, 凝集しやす くなり, 沈降の初期段階で連続体化したと推測され 
る。このような完全に粒子同士が接触しなくても凝集 する挙動は，高分子添加剤による架橋凝集の影響を考 慮したシミュレーションで行われた6)。架橋凝集モデ ルのシミュレーションでは, 沈降直後に初期粒子濃度 を保ったまま連続体化する結果が示されたことから， この実験の挙動と合っていることがわかった。今後 は, 本シミュレーションに粒子間ポテンシャルの影響 を考慮し，架橋凝集距離が及ぼす沈降挙動への影響に 関して解析を行う予定である。

\section{4. 結言}

大小 2 粒子系混合スラリーにおける沈降実験およひ 沈降シミュレーションより以下のことが明らかとなっ た。
1. 粒子の衝突挙動より定義した単位深さ $H_{\mathrm{u}}$ および 単位時間 $T_{\mathrm{u}}$ により, シミュレーションによる粒子 の集合状態を濃度によらず整理することができた。

2. 粒子濃度が $10 \mathrm{vol} . \%$ 末満の場合では, 分散粒子 が沈降過程において衝乫し凝集体を形成し，凝集体 の成長により粒子がパーコレートし，沈降界面を形 成することが示唆された。

3. 1., 2. より, 粒子濃度を低下させても, 沈降場の 長さを十分長くすることにより，沈降界面を形成す ることが示唆される。

4. 粒子濃度が $10 \mathrm{vol} . \%$ 以上の場合では, 低い場合 と異なり，沈降直後に連続体化することにより沈降 界面を形成することがわかった。

\section{Nomenclature}

$a$ : dispersion index

$d_{\mathrm{pi}}$ : particle diameter of $i$ th particle

$d_{\mathrm{pL}}$ : diameter of large particle

$d_{\mathrm{pS}}$ : diameter of small particle

$f_{\mathrm{L}}$ : solid fraction of larger particles in binary dispersion (area fraction in 2-dimension, volume fraction in 3-dimension)

$(-)$

$f_{\mathrm{NL}}$ : number fraction of larger particles in binary dispersion

$f_{\mathrm{NS}}$ : number fraction of smaller particles in binary dispersion

$f_{\mathrm{S}}$ : solid fraction of smaller particles in binary dispersion (area fraction in 2-dimension, volume fraction in 3-dimension)
(-) $H_{\mathrm{u}}$ : unit height (m)

(m) $k$ : coordination number (-)

(m) $m$ : number of agglomerate-construction large particles

$n$ : number of agglomerate-construction small particles

$T_{\mathrm{u}}$ : unit time

$v_{1 \mathrm{~s}}$ : terminal velocity of one small particle

$v_{\mathrm{L}}$ : terminal velocity of large particle

$v_{\mathrm{S}}$ : terminal velocity of small particle

$\phi$ : solids content in slurry

$\phi_{0}$ : initial solids content in slurry

$\phi_{i}$ : solids content of $i$ th particle in slurry
$(-)$

$(\mathrm{m} / \mathrm{s})$ $(\mathrm{m} / \mathrm{s})$ $(\mathrm{m} / \mathrm{s})$

$(-)$

$(-)$

$(-)$

\section{References}

1) Sunada, H.: "The Structure of the Sedimentation Bed”, J. Soc. Powder Technol., Japan, 7, 3-14 (1970)

2) Suzuki, M., A. Yagi, T. Watanabe and T. Oshima : "Estimation of Void Fraction in Three Component Random Mixture of Sphere", Kagaku Kogaku Ronbunshu, 10, $721-727$ (1984)

3 ) Suzuki, M., H. Ichiba, I. Hasegawa and T. Oshima : "Void Fraction of Multicomponent Randomly Packed Beds with Size Distribution”, Kagaku Kogaku Ronbunshu, 11, 438-443 (1985)

4) Suzuki, M. and T. Oshima: "The Estimation of the Void Fraction in a Cohesive Sphere Bed with Size Distribution", J. Soc. Powder Technol., Japan, 22, 612617 (1985)

5) Kamiya, H. and G. Jimbo: "Simulation of Aggregate Packing and Anlaysis of Aggregating Process of Ultra-Fine Powder by Brownian Dynamics Method", J. Soc. Powder Technol., Japan, 17, 837-845 (1991)
6 ) Tsubaki, J., H. Mori and T. Sugimoto : "Network Formation Mechanism of Fine Particle in SuspensionSimulation on the Influence of Particle Bridging-" J. Soc. Powder Technol., Japan, 37, 92-99 (2000)

7 ) Sugimoto, T., H. Mori and Tsubaki J. : "Network Formation Mechanism of Fine Particle in SuspensionSimulation on the Structure Formation in Binary Dispersions", J. Soc. Powder Technol., Japan, 37, 100$106(2000)$

8 ) Suzuki, N. : “Kagaku Kogaku Benran”, pp. 733-738, Maruzen (1988)

9 ) Sanbuichi, M., H. Nakakura and K. Osasa : "Zone Settling Rates of Slurries and Effect of Initial Height", J. the Mining Institute of Japan, 103, 109 (1988)

10) Tsubaki, J. : "A discussion of how to describe the assembled fine particles", Preprint of the 37th Symposium on Powder Science and Technology, 58-61 (1999) 